\title{
The practice and perception of unexpected topic switching in Mandarin Chinese
}

\author{
Weihua Zhu \\ University of Wisconsin-Madison \\ wzhu34@wisc.edu
}

\begin{abstract}
In this paper, I combine a model of context, practice, and perception with a discursiveinteractional approach to investigate the moral order of the practice and perception of unexpected topic switching in the context of everyday communication in mainland China, using data derived from recorded mundane conversations in Mandarin and playback with native Chinese speakers. Results show that the speakers initiate, react to, and perceive unexpected topic switching as a part of appropriate interactional norms. The analyst understandings, participant understandings, and metaparticipant understandings that I uncover indicate the influence of the sociocultural context, interactional context, and personal context on the practice and perception of unexpected topic switching.
\end{abstract}

Keywords: practice; perception; moral order; topic switching; Chinese

\section{Introduction}

A discourse topic refers to a stretch "of discourse, with an identifiable and sustained focus, and bounded by specific moves that led to a recognisably complete or partial change of focus" (Morris-Adams 2014, 152). We normally start a topic after the speaker mentions it, the addressee acknowledges it, and one of them continues it (Geluykens 1993), which means that we establish a topic after three turns (Tryggvason 2004). We expect to develop a topic coherently on the basis of prior talk (Tannen 1990). To signal the change of topic, the second speaker should deploy "an explicit (either verbal or nonverbal) digressive marker" (Giora 1998, 80). The digressive marker functions to prepare interactants for topic switching. We tend to implement this type of topic switching in accordance with "a system that regulates social life through psychological processes such as values, virtues, norms, and practices" (Spencer-Oatey \& Kádár 2016, 74). The system is familiar to "members of a sociocultural group or relational network" and serves as the underpinning of their evaluations of what is (im)polite or (in)appropriate (Kádár \& Haugh 2013, 67). 
In contrast, unexpected topic switching has rarely been explored. I define unexpected topic switching as a communicative act that occurs when the second speaker brings up a new topic without providing any cues, discourse markers, or smooth transitions before the current speaker signals the completion of the current topic. The new topic has not been mentioned in the preceding talk and it continues for at least three turns in the following talk. Researchers have explicitly or implicitly associated unexpected topic switching with inappropriateness (e.g., Murata 1994). Coon and Schwanenflugel $(1996,6)$ posited that "when a speaker breaks into the middle of a speaker's unit to change the topic, it can be seen as an interruption. Furthermore, when a second speaker changes the topic at a TRP [transition-relevance place], it may be viewed as an interruption if the current speaker has not finished discussing the current topic". Interruptions, according to Schegloff (2001), are problematic.

Nevertheless, I argue that unexpected topic switching in Mandarin Chinese in informal contexts is not a problem or moral transgression. Moral orders are context-specific. The contention that the practice of unexpected topic switching is perceived as inappropriate does not remain universally valid across contexts. Since language, society, and mind are all interwoven in context, variation in context can cause the human mind to process and interpret language use and sociocultural activities differently (Gumperz 1992). Context plays a crucial role in the moral order concerning the ways of practicing and perceiving unexpected topic switching. Hence, I combine a model of context, practice, and perception with Kádár \& Haugh's (2013) discursive-interactional approach to investigate how native Chinese speakers practice and perceive unexpected topic switching in the context of everyday communication in mainland China.

\section{A model of context, practice and perception}

Researchers did not recognize the importance of context to the understanding of the practice and perception of (im)politeness in interactional conversation until recently. Prior studies have employed native-speaker intuitions to evaluate single utterances out of context (e.g., Austin 1962; Lakoff 1973), or made the evaluations from the speaker's point of view (Grice 1975). Although Brown and Levinson (1987) acknowledged the impact of the interactional context, such as social distance, relative power, and ranking of imposition, they did not consider the sociocultural context, which refers to social factors such as settings, regions, and temporality. 
Their universal politeness framework has been questioned (e.g., Matsumoto 1988; Byon 2006).

We should admit that the sociocultural context constrains interactants' moral ideologies and the implementation of these ideologies in conversational interaction, although the East-West divide is not clear-cut in how people sustain moral orders due to the shared commonalities among cultures (Leech 2007). Culture consists of "assumptions and values, orientations to life, beliefs, policies, procedures and behavioral conventions that are shared by a group of people, and that influence (but do not determine) each member's behavior and his/her interpretations of the 'meaning' of other people's behavior" (Spencer-Oatey 2008, 3). Interactants from different cultures or regions may hold varying beliefs, develop culturally-based expectations and moral orders, and perform and interpret communicative acts differently. They expect certain norms of speech and behavior in certain regions or settings and judge people to be (in)appropriate based on their disparate normative anticipations (Haugh 2013) and understandings of moral orders in their indigenous cultures. If we did not consider the sociocultural context in the analysis of the (in)appropriateness of interactants' communicative acts, neither universalism nor relativism would be justifiable (Leech 2007).

Additionally, we should value the in-depth analysis of local specificities in the interactional context and "account for contextualized expressions of politeness and impoliteness" (Kádár \& Mills 2011, 8). (Im)politeness is "interactionally achieved through the evaluations of self and other (or their respective groups) that emerge in the sequential unfolding of interaction" (Haugh 2007, 295). Local specificities in the interactional context, such as goals, social distance, or verbal/nonverbal cues, can influence interactants' negotiation and interpretation of (im)politeness and shape practice-based norms (Mills 2009; Bousfield \& Locher 2008) in a community. Including the interactional context in the analysis of the (in)appropriateness of interactants' communicative acts is essential for us to comprehend the moral orders of the practices of communicative acts and the perceptions of the (in)appropriateness of communicative acts.

Finally, interactants' personal context of sex, age, temperament, habits, awareness, and beliefs can influence the moral order of how interactants perform and interpret a communicative act. For example, Hong (1997) found that higher-status female speakers made requests to lowerstatus addressees more politely than higher-status male speakers and that lower-status men used more compliments than women when making requests to higher-status addressees. Pan (2000) postulated that rank, age, 
sex, and relationship did not seem to carry equal weight in different contexts. In family gatherings, juniors appeared to be indirect, compliant, and respectful to seniors, just as females were to males in the conversational interactions she collected. But in official settings, the power affiliated with one's age and sex did not have more influence on speech and behavior than the power coming from rank.

To summarize, the context that can shape the moral order of a communicative act encompasses the sociocultural context, the interactional context, and the personal context. More specifically, the sociocultural context is related to when and where a communicative act emerges. The interactional context involves elements of communication such as interactional goals (Spencer-Oatey 2008, 2009), risks, conversation topics, verbal/nonverbal cues, social distance, and status difference. The personal context includes individual traits such as interactants' sex, age, education, temperament, habits, awareness, and beliefs. The three types of context have some degree of overlap and mold the moral order of a communicative act. For instance, the interactional contextual element - status difference - is connected to the sociocultural contextual element-temporality. Status difference between professors and students during the period of Cultural Revolution in China did not prevent students from denouncing professors. But these days, status difference between professors and students is one of the reasons why students do not call professors by their first names. Meanwhile, status difference is related to the personal contextual element - age. Age difference might entail status difference and make Chinese children or juniors refrain from interrupting seniors' speeches (e.g., Gao 1998), although Zhu $(2016 ; 2017)$ found little influence of age difference on the practice and perception of extended concurrent speech in the informal mundane conversations in Mandarin. We can see the interplay of context, practice, and perception in the following model (Figure 1).

As Figure 1 shows, context, practice, and perception are interconnected in a dynamic, fluid, and complex way. Practice forms perception while perception influences practice. Context shapes practice and perception while practice and perception establish context. Context is constructed, deconstructed, reconstructed, and co-constructed in practice and by perception. In practice, context is interactional, emergent, and fluid because interactants tend to parley and build context in conversation. Furthermore, interactants' perceptions are partially responsible for their moral expectations and have an impact on how they practice a communicative act in context. Meanwhile, the same practice "may be understood as impolite by some but less impolite or not impolite at all by others" (Culpeper 2011, 15) because perception is sensitive to context. 


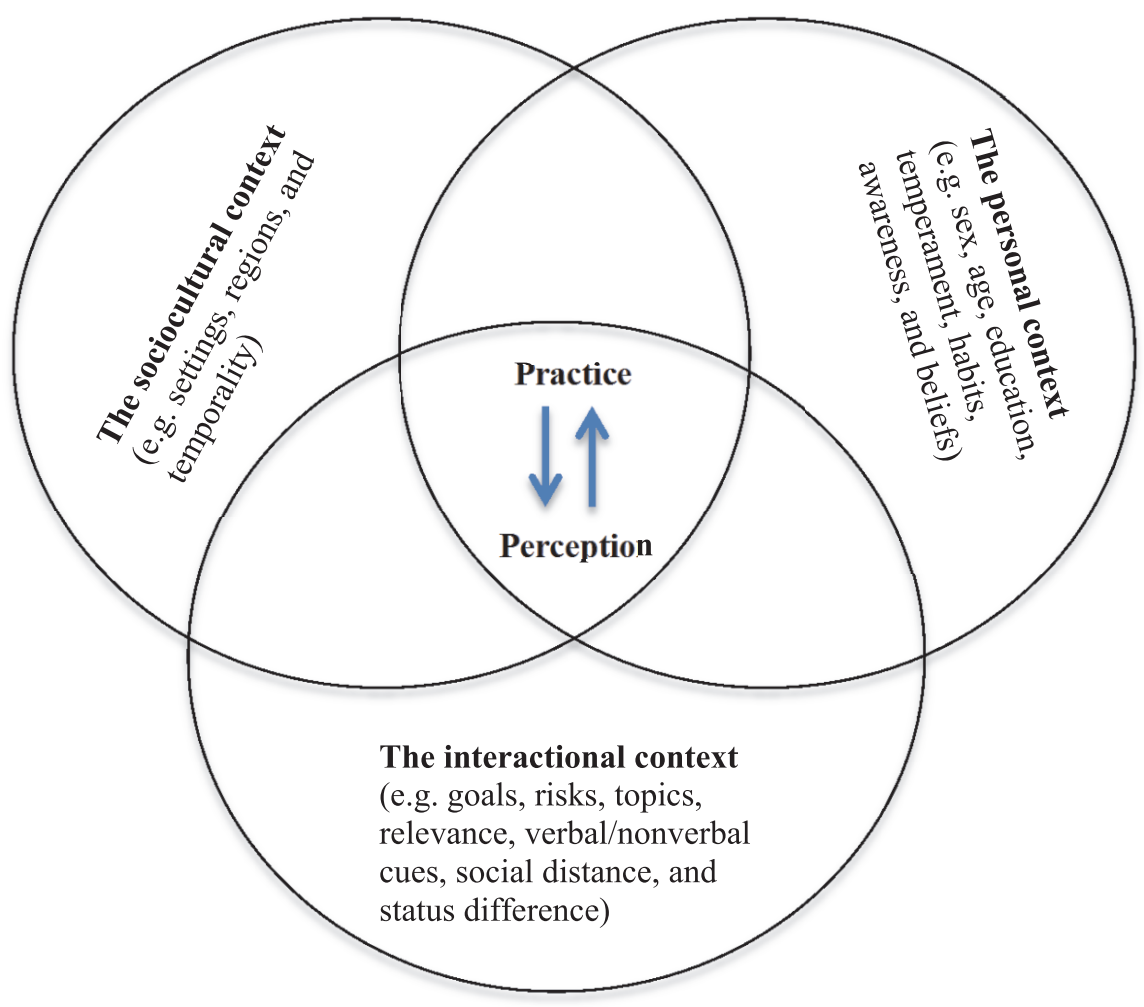

Figure 1: A model of context, practice, and perception

The model of context, practice, and perception also demonstrates that the sociocultural context, the interactional context, and the personal context are not completely separable. The three types of context penetrate into each other's territories, as previously discussed with the example of status difference, and affect practice and perception simultaneously. We can employ the three types of context to account for how we perform and perceive a communicative act. How we perceive a communicative act affects how we perform it. In turn, if we perform the communicative act regularly like a routine, it can inaugurate our perception of it as normal. Eventually, our routine practice and conventional perception of the communicative act construct a moral order and help to build the personal context, the interactional context, and the sociocultural context of the communicative act. 


\section{The discursive-interactional approach}

Just as the above model can display the important role of context in the practice and perception of a communicative act, Kádár \& Haugh's (2013) discursive-interactional approach can manifest various understandings of a communicative act. The discursive-interactional approach situates (im)politeness in the circumstances under which a communicative act occurs by taking advantage of diverse data sources to examine the act. Using this approach, through linguistic and metalinguistic analyses on the basis of theoretical arguments and empirical evidence, we can uncover "understandings and interpretations" (Bennett 1981, 184) regarding social and cognitive aspects from analysts' etic and participants' emic perspectives. Any one perspective alone cannot accurately reflect either researchers' or interactants' viewpoints concerning how interactants employ and perceive linguistic/metalinguistic forms and how they observe or violate moral orders within certain contexts (Garcés-Conejos Blitvich 2013). Integrated perspectives derived from varying sources or contexts are comparatively more conclusive, systematic, and comprehensive (Haugh 2007).

The discursive-interactional approach aims to investigate "the variable and contested, yet simultaneously taken-for-granted and unseenunless-noticed qualities of politeness" (Kádár \& Haugh 2013, 257). Since we tend to take normal practice for granted, we should embrace all kinds of perspectives such as "participant/metaparticipant understandings," "emic/etic conceptualizations," "analyst/lay-observer understandings," and "theoretical/folk-theoretic conceptualizations" (ibid., 6) to figure out whether a communicative act is (in)appropriate. We could gain these different perspectives from various data sources, such as historical texts, spontaneous conversations, discussion boards, interviews, questionnaires, and diaries. In what follows, I integrate the model of context, practice, and perception and the discursive-interactional approach to scrutinize the practice and perception of unexpected topic switching in mundane conversations in Mandarin Chinese in informal settings.

\section{The case of unexpected topic switching}

I test the operation of the model of context, practice, and perception and the discursive-interactional approach in an empirical study on unexpected topic switching. Researchers (e.g., Covelli \& Murray 1980; Goldberg 1990) have deemed unexpected topic switching inappropriate although it frequently emerges in the mundane Chinese conversations I collected. 
Few studies have examined interactants' perceptions of unexpected topic switching in everyday communication in Mandarin Chinese, although Wu (2004) discussed éi-prefaced topic switching in Mandarin. To fill this knowledge gap, I gathered three types of data - mundane conversations in Mandarin Chinese, playback (Gumperz 1982; Tannen 1984), and questionnaires for participants' demographic information (see Appendix A).

I recorded approximately 97 hours of spontaneous conversations in Mandarin in a southeastern city of mainland China. These mundane conversations occurred at places including restaurants, condominiums, or community centers. The collected conversations provide us with real-world examples of unexpected topic switching, which I analyze to reveal analyst understandings. The participants engaged in the conversations are comparatively equal-status nonfamilial native Chinese speakers who do not have known conflicts of interest. "Equal-status" is a relative notion in this study. Status difference that could result from disparities by sex, age, education, and income might blur in the casual conversations. The participants are friends, acquaintances, or strangers from various families and workplaces. Their major interactional goal is to socialize with one another in informal settings. The conversations involve diverse mundane topics that are inconsequential and low-stakes. The verbal/nonverbal cues are sent out in a non-aggressive manner - with a low pitch, soft volume, and flat tone of voice. The participants' initiations of and reactions to unexpected topic switching indicate participant understandings of unexpected topic switching in the context of everyday life in mainland China. What is important is "whether and how participants interpret, represent and make use of such "external" constraints, and especially how they do so in situated interaction" (van Dijk 2006, 163).

It is uncertain how participants perceive unexpected topic switching until we elicit their moral evaluations and emic perspectives (Locher \& Langlotz 2008; Kádár \& Haugh 2013). Metapragmatic data can give us access to first-order understandings of (im)politeness (e.g., García \& Terkourafi 2014). Therefore, I conducted playback, a type of semi-structured interviewing, with ten of the participants. Each of them was interviewed alone in Mandarin for about thirty minutes and promised anonymity. The ten participants might be the first speaker whose topic the second speaker changes, the second speaker who initiates unexpected topic switching, or "side participants" who are not directly addressed (Kádár \& Haugh 2013, 88). They watched six conversation clips involving unexpected topic switching. Right after that, I asked them whether they had noticed anything abnormal in the conversations. Then, they evaluated the six instances of unexpected topic switching and justified their evaluations.

Acta Linguistica Academica 66, 2019 


\subsection{Analyst understandings of the sociocultural context}

In this section, I present analyst understandings concerning the sociocultural context of the collected conversations. The conversations occurred in a southeastern city of mainland China in the contemporary era. Many historical politeness norms have been transformed, conventional expressions have been removed, and Neo-Confucianism has been replaced by new ideologies and social practices that may allow for unexpected topic switching. For instance, in Chinese conversations, people seem to systematically use subtle discursive strategies instead of honorifics and lexical politeness (Pan \& Kádár 2011).

Moreover, another sociocultural contextual factor - the informal setting - has framed (Goffman 1974) the practice of unexpected topic switching in the collected conversations, and provided "resources for its appropriate interpretation" (Goodwin \& Duranti 1992, 3). In the informal setting, making a smooth transition for a new topic is not much of a concern. Instead, getting involved to know and to be known in the practice seems to be the priority (e.g., Freed 1999). Active engagement in the informal setting may lead to the initiation of unexpected topic switching. Conversely, in a formal context where the maintenance of social order is essential, the use of unexpected topic switching would be perceived as inappropriate because it violates organizational rituals, the society's moral rules, or "normative expectations" (Spencer-Oatey \& Kádár 2016, 74).

\subsection{Participant understandings of the interactional context}

Because unexpected topic switching in the collected conversations is often re-contextualized as an interactive phenomenon, "a joint and collaborative activity" (Haugh \& Bargiela-Chiappini 2010, 2074), I examine samples in real-life interaction. Analysis of the interactional context can contribute to our comprehension of the practice and perception of unexpected topic switching and reveal participant understandings of the varying initiations of and reactions to unexpected topic switching. Understandings of (im)politeness come into existence "on the spot," as (im)politeness is "constantly negotiated" and "renegotiated" (Locher 2004, 264) in the interactional context that both speakers and addressees actively build (Locher 2006). Interactants tend to "draw from certain sets of expectancies in coconstructing interaction in localized, situated contexts" (Kádár \& Haugh 2013, 137) and evaluate (im)politeness within social practices (Haugh 2013). Interactants' practice-based expectations of interactional norms 
conserve moral orders which in turn affect the interactants' perceptions of actual interactions, although the interactants might be unaware of the influence. This means that participant understandings of communicative acts in ongoing conversations tend to be tacit.

Participant understandings are shaped by the interactional context of the collected conversations. Interactional contextual elements, such as status, sex, age, education, social distance, conversation topics, interactional goals, and verbal/nonverbal cues, can partially account for why the participants react to the following instances of unexpected topic switching in a normal way. A more detailed analysis of the instances can reveal implicit participant understandings of the practice of unexpected topic switching (see Appendix B for transcription conventions).

Consider Excerpt (1) which exemplifies how the current speaker switches a topic unexpectedly in order to engage a side participant. Júmù, female, and Jú, female, are best friends working for different departments of the same college. Jú and Wán, female, are college teachers working for different universities in the same city. Jiàn, female, worked in Jú's college before moving away to pursue a Ph.D. degree. Júmù is in her fifties; Wán is in her forties; Jú and Jiàn are in their thirties. Jú's husband has been promoted to become an assistant director of a construction department of the provincial government. This summer, Jiàn returns to the city to visit friends and family. One late afternoon, Júmù, Jú, Jiàn, and Wán meet in a neighborhood garden and start to catch up.

(1) Excerpt from Ping

a. 剑： (looks at Jú) 他干嘛跑来跑去啊?

Jiàn: (looks at Jú) Why does he run around for his job?

b. 菊慕: (looks at Jiàn) 在这里当 [干部呗， ]

Júmù: (looks at Jiàn) At this place, he works [as a leader,]

c. 菊: (looks at Jiàn) [干部更]好。这边厅里头=

Jú: (looks at Jiàn) [Better as a] leader. In this bureau=

d. 菊慕: =在这边当干部呗, 干的事情就多呗。

Júmù: =at this place he is a leader. He handles many things.

e. 剑: (looks at Júmù) 挺好的, 非常不错。那=

Jiàn: (looks at Júmù) That's good, very good. Then=

f. $\rightarrow$ 菊: (turns to Wán) =纨姐, 你呢? 你怎么样?

$\rightarrow$ Jú: (turns to Wán) =Sister Wán, what about you? How are you?

g. 纨: (smiles at Jú) 老样子呗。

Wán: (smiles at Jú) Same old, same old. 
h. 菊: (looks at Wán) 什么叫老样子撒?

Jú: (looks at Wán) What do you mean by same old same old?

i. 剑: (looks at Jú) 老样子啊。

Jiàn: (looks at Jú) Same old, same old.

j. 纨: (looks at Jú) 一点没变, 原来的状况, 原来的情形。

Wán: (looks at Jú) No changes at all. I've been in the same situation.

Excerpt (1) shows that the participants seem to understand that their interactional goal is to have a high-involvement (Tannen 1984) conversation. Lines $(1 \mathrm{a}-\mathrm{e})$ focus on Jú's husband about whom Jiàn and Wán do not know much. Jú and Júmù cuts in each other's words to provide an explanation (1b-d). These interruptions do not seem to offend them, not even Júmù who is older, which indicates a solid relationship between them. Before Jiàn completes her utterance (1e), Jú changes the current subject to engage with Wán (1f). Although Jú provides no signals that would prepare Júmù and Jiàn before switching the topic, Wán gladly answers her question (1g) and Jiàn is obviously willing to contribute to the new topic (1i). The participants' reactions to this sudden change of topic suggest a shared understanding of their relatively close relationships having more value than age difference in this interactional context. The new topic encourages Wán to share personal information, which can enhance the participants' interpersonal relationships (Davidson \& Duberman 1982).

Excerpt (2) is an instance of a participant switching a topic abruptly to seek information. Zhēnlì, a female entrepreneur selling everyday necessities, Jiàn, a female Ph.D. student of linguistics, and Lán, a female lawyer of a technology company, are old friends in their thirties. They went to the same middle school and high school. Zhēnlì and Lán had been neighbors before Lán moved away with family to another city in her last year of high school. Twenty years after losing touch, they finally meet at their high school reunion in the city of the data collection. One morning, after they get up in a hotel room, they talk about the old classmates they remember or try to remember.

(2) Excerpt from Zhenling

a. 贞丽: (looks at Lán) 反正我觉得好像我们班上是

Zhēnlì: (looks at Lán) Anyway, I think in our class there was someone

b. 有个江 (indistinct)。

called Jiāng (indistinct).

c. 兰: (looks at Zhēnlì) 我知道, 我记得。

Lán: (looks at Zhēnlì) I know. I remember. 
d. 贞丽: (turns to Jiàn) 我就是_那叫什么?

Zhēnlì: (turns to Jiàn) I just_ what was his name?

e. 剑: (looks at Zhēnlì) 我也不记得。我告诉你=

Jiàn: (looks at Zhēnlì) I have no idea. I'm telling you=

f. $\rightarrow$ 兰: (looks at Jiàn) =我们上午有安排吗

$\rightarrow$ Lán: (looks at Jiàn) =Do we have any arrangement this morning?

g. 还是就_就坐在这儿。

Or just_ just sitting here?

h. 剑: (looks at Lán) 没有。我就是问你啊, 我就是跟你

Jiàn: (looks at Lán) No. I just ask you. I just

i. 聊聊天哪, 我陪你啊。

chat with you. I'm here to keep you company.

j. 兰： (smiles at Jiàn) 那就不要_[就在这儿困。]

Lán: (smiles at Jiàn) Then don’t [just look sleepy while you're here.]

k. 剑: (looks at Zhēnlì) [陪完你然后]

Jiàn: (looks at Zhēnlì) [After keeping you company,]

1. 明天再_明天再陪我父母。

I'll go to keep my mom company tomorrow.

In lines (a-e) of (2), Zhēnlì, Lán, and Jiàn talk about one of their former classmates whose name has the Chinese character 江 Jiāng. Before Jiàn finishes her words (2e), Lán cuts in to seek information about the reunion activity for that morning ( $2 \mathrm{f}$ ), which has nothing to do with the previous topic. Despite the interruption and unexpected topic switching, Jiàn follows Lán's lead and answers her question $(2 \mathrm{~h})$. The participants have a shared understanding that the goal of the reunion is to retrieve or maintain relationships in face-to-face fun activities. It is appropriate to jump from one topic to another in a low-stakes conversation. The informal setting, the participants' interactional goal, their relational history, and the nature of their conversation make the use of ritual language excessive and even impolite in contemporary China (Pan \& Kádár 2011). This might explain why Lán does not hide her eagerness to know the reunion arrangement and Jiàn does not mind the interruption and unexpected topic switching.

In addition to seeking information, the participants employ unexpected topic switching to provide information. Consider Excerpt (3). Qiáng is a female entrepreneur selling computer hardware; Jiàn is a female Ph.D. student of linguistics; Yùhú is a female entrepreneur running a foreign trade company; and Fán is a male customs officer of the government. They 
are acquaintances in their thirties who grew up in the city of the data collection. They went to the same middle school and high school. After high school, Qiáng and Yùhú have stayed in touch, but they lost contact with Jiàn and Fán for twenty years until they meet again at their high school reunion held in the city.

(3) Excerpt from Lan3

a. 强: (looks at Yùhú) 你们家有多少年没说?

Qiáng: (looks at Yùhú) For how many years hasn't your family spoken it?

b. 我们家也好多年不说了。

Mine hasn't spoken it for many years.

c. 剑: (looks at Qiáng) 以前经常说, 等于说。

Jiàn: (looks at Qiáng) That means, you spoke it very often before.

d. 玉湖: (looks at Jiàn) 这是梁山话嘛。我们=

Yùhú: (looks at Jiàn) This is the Liángshān dialect. We=

e. $\rightarrow$ 凡: (looks at Qiáng) =强, 你那天摘的丝瓜

$\rightarrow$ Fán: (looks at Qiáng) =Qiáng, the loofah you picked that day

f. 是贞丽家的。

belonged to Zhēnlì's family.

g. 强: (looks at Fán) 哦, 贞丽家的丝瓜。甘花偷的。

Qiáng: (looks at Fán) Oh, Zhēnlì's family's loofah. Gānhuá stole it.

h. 凡: (smiles at Qiáng) 现在现在不叫偷,

Fán: (smiles at Qiáng) Nowadays it's not called stealing,

i. 叫摘了贞丽家的瓜。

but called picking Zhēnlì's family's loofah.

j. 玉湖: (nods)@@@

Yùhú: (nods)@@@

Similar to excerpt (2), the participants in this conversation share an understanding that it is ok to switch between different topics in an informal setting such as a high school reunion. In lines (3a-d), Qiáng, Jiàn, and Yùhú discuss the local dialect they have not used in their own homes. Before Yùhú finishes (3d), Fán mentions that the 丝瓜 'loofah' Qiáng picked from someone's yard belonged to Zhēnlì's family ( $3 \mathrm{e}-\mathrm{f})$. The new topic is not prefaced with cues or markers. Qiáng reacts to Fán's brusque topic switching by contributing to the new topic $(3 \mathrm{~g})$, which suggests that she perceives the topic as appropriate. The choice of topic can influence people's perceptions of interrupters (Chambliss \& Feeny 1992). Yùhú, who 
Fán cuts off, nods and laughs $(3 \mathrm{j})$. The nonverbal cues indicate that she does not mind being interrupted and that she also embraces the new topic. This endorses Pan and Kádár's $(2011,124)$ contention that "highly contextualized and discursive use of linguistic resources" tend to be employed in contemporary China to signal the (in)appropriateness of communicative acts.

In addition, the participants often change topics to pay compliments or offer suggestions. Excerpt (4) is an example. Jiàn is a female Ph.D. student of linguistics and Jùn is a female college teacher. Jiàn worked in Jùn's college before moving away for her graduate program. Both are in their thirties. The following dialogue occurs when Jiàn returns to visit friends and family. One day, Jiàn runs into Jùn in a neighborhood garden before dinner. During their catch-up, Jiàn is happy to learn that Jùn is married with a baby girl. They start to talk about when their babies were born.

(4) Excerpt from Jiping

a. 俊: 哦, 差不多_我是 [三十六七]

Jùn: Oh. Almost_ I was [thirty-six seven]

b. 剑: [三十七周。]

Jiàn: [Thirty-seven weeks]

c. 俊: 我三[十六七周]

Jùn: I was thirty-[six seven weeks]

d. 剑: [三十七周, ]我的也是提前了。

Jiàn: [Thirty-seven weeks]. Mine also came early.

e. $\rightarrow$ 俊: 不错, 你还是这么瘦是。

$\rightarrow$ Jùn: Not bad. You're still so slim.

f. 剑: 我还瘦啊? 你看我一吃完饭就坐那看书啊,

Jiàn: Am I? Look, I sit there reading books right after each meal.

g. 我后面发现这里不行了 (points at her waist)。

Later I find that it looks bad here (points at her waist).

h. 俊: 什么呀, 你比我瘦。

Jùn: What? You're slimmer than me.

i. 剑: 你一点都不胖。

Jiàn: You're not fat at all.

j. $\rightarrow$ 俊: 你千万别回来撒哈。

$\rightarrow$ Jùn: Don't you come back to work here.

k. 剑: @@@ 为什么?

Jiàn: @@@Why? 
1. 俊: 你跟我做邻居就可以咯。你不要到南大,

Jùn: You can be my neighbor. You don't return to Nándà.

$\mathrm{m}$. 你干嘛要来南大?

Why would you come back to Nándà?

n. 剑: 那我去哪里啊?

Jiàn: Then where should I go?

Excerpt (4) contains three disparate topics although it is short. The two participants, Jùn and Jiàn, move from the first topic of when they gave birth to their babies (4a-d), to the second topic of their body images $(4 \mathrm{e}-\mathrm{i})$, and then to the third topic of where Jiàn should work $(4 j-n)$. None of the topic transitions are signaled with verbal/nonverbal cues or "digressive markers" (Giora 1998, 80). However, immediately after Jùn's unexpected topic switching, Jiàn responds with a relevant question that contributes to the development of the newly proposed topic. This manifests the participant understanding of "joint enthusiasm" (Natale et al. 1979, 875) and the moral order of topic management in a casual conversation. The participants do not need to prepare each other for the next topic or comply with a moral rule of coherent, prefaced topic switching because they are acquaintances who are familiar with each other's thinking or behavior patterns. They are "on an equal footing" to exchange ideas (Angouri \& Locher 2012,1950 ) because they have no institutional power over each other or known conflicts of interest. If they waited for or gave a signal to change topics, it would be an index of them being over-polite and distant from each other.

It is not surprising to see the participants changing topics suddenly to share opinions. The following conversation at a restaurant is among one lecturer of electrical engineering and two full-time Ph.D. students from different universities. Jiàn, a female in her mid thirties, and Cái, a male in his mid forties, are friends. They meet Kān, a male in his early thirties, for dinner for the first time because they, like other Chinese people, often expand their social networks through various activities including social dining (Bian 2001). Kān, Jiàn, and Cái appear to share an understanding that their interactional goal is to build nascent relationships and enhance old relationships.

(5) Excerpt from Dinner_Gan2

a. 才: (looks at Jiàn) 你上次记得吧, 拿回来

Cái: (looks at Jiàn) Do you remember last time? After he 
b. 拿回去, 结果最后怎么了?

took them home, what happened?

c. 剑: @@没人吃。

Jiàn: @@ No one ate them.

d. 才: (turns to Kān) 上次一个人拿_

Cái: (turns to Kān) Last time he alone took_ all that was

e. 十来个人嘛, 每个人都发一个嘛,

given to about ten people. Every one received one.

f. 结果他全带回去了。

As a result, he took them all home.

g. $\rightarrow$ 勘: (looks at Cái) 我觉得结婚就是个大问题,

$\rightarrow$ Kān: (looks at Cái) I think it's a big problem to get married.

h. 一结婚就有小孩了。

Once you're married, you'll have kids.

i. 剑: (looks at Kān) 没时间。

Jiàn: (looks at Kān) You wouldn't have time.

j. 勘: (turns to Jiàn) 还真没时间, 不是一个人的事,

Kān: (turns to Jiàn) You wouldn't have time. Not just one person.

k. 一个人怎么都好说。 [我的时间就是 $]=$

It's easier to deal with myself. [My own time is just]=

1. 才: (looks at Kān) [一个人好说。]=

Cái: (looks at Kān). [It's easier to be single.]=

m. 勘: (looks at Jiàn)=我的时间, 自己安排。

Kān: (looks at Jiàn) =my time, I make the arrangement.

Prior to line (5g), Cái and Jiàn share a fun story that happened at the same restaurant. While everyone else is still in that story, Kān expresses his opinion of marriage as a big problem $(5 \mathrm{~g})$. The sudden change of subject does not seem to disrupt the ongoing conversation or receive resistance from the other participants. As reactions, both Jiàn and Cái lend support to Kān's position respectively in line (5i) and line (5l). They discuss the new topic collaboratively and build on each other's contributions vigorously. This possibly reveals the participant understanding of Kān's initiation of unexpected topic switching as appropriate. If they perceived the unexpected topic switching as an act of strategic impoliteness, they would make negative comments, use emotionally loaded words, display signs of distress (Culpeper et al. 2003), or simply leave the conversation. This might be 
due to the fact that the trivial mundane topics do not entail emotional responses, as Kuhn (1991) asserted that the choice of topic affects people's informal reasoning.

The participants also switch topics unanticipatedly to share life experiences. Excerpt (6) is a part of a conversation among Yí, Xīn, and Jiàn in Jiàn's condominium during a summer break. Jiàn is a female Ph.D. student, $\mathrm{X} \overline{\mathrm{i}} \mathrm{is}$ a female associate professor, and Yí is a female lecturer. They are all in their thirties. Both Xīn and Yí had worked as visiting scholars at American universities the year before they met. They became acquainted with Jiàn through a professor they knew a couple of months before the day of the data collection.

(6) Excerpt from ChiScho2-6

a. 新: (looks at Yí) 新鲜的东西哈, 你可能要碰

Xīn: (looks at Yí) Eye-opening things, you might come across them

b. 好久你才能碰完, 还不一定碰得完。

for a while before you're not amazed any more. Or they will never end.

c. 怡: (looks at Xīn) 对。

Yí: (looks at Xīn) Yes.

d. 剑: (looks at Xīn) 平常出去转悠转悠, 看看

Jiàn: (looks at Xīn) Get out of the condo, wander around, and see

e. [别人怎么做。]

[how others handle things.]

f. $\rightarrow$ 新: (turns to Jiàn) [我那天那天] 碰到一个访问学者,

$\rightarrow$ Xīn: (turns to Jiàn) [I that day that day] ran into a visiting scholar.

g. 然后正好在车上碰见他, 问他干嘛=

We were on the same bus by accident. I asked him what=

h. 剑: (looks at Xīn) $=[$ 一个访问学者 $]$

Jiàn: $($ looks at $\mathrm{X} \bar{n} n)=[$ a visiting scholar $]$

i. 怡: (looks at Xīn) $=[$ 哪个系的 $]$ ?

Yí: $($ looks at $\mathrm{X} \bar{n} n)=[$ Which department?]

j. 新: (looks at Yí) 好像是个_是理科的那种。

Xīn: (looks at Yí) It seemed_ to be a science department.

At the beginning of the conversation, Yí, Xīn, and Jiàn have expressed their amazement about eye-opening encounters in the U.S. But before they complete the current topic and Jiàn finishes her words (6e), Xīn abruptly cuts in to introduce a new topic about a visiting scholar she ran into 
one day in the U.S. (6f), which results in long overlapping. Covelli \& Murray (1980) posited that topic management that is not right-angled, such as cutting off the current topic precipitously, seriously contravenes the current speaker's rights and is irritating. But Jiàn and Yí seem fine with Xīn's unexpected topic switching that contains "few coherent-cohesive ties with the interrupted utterance" (Goldberg 1990, 891). They do not request finishing the old topic. Instead, they actively develop the new topic and even cut Xīn off to express ideas simultaneously $(6 \mathrm{~h}-\mathrm{i})$. Xīn also cooperates with them and answers Yís question calmly $(6 \mathrm{j})$. The participants appear to not expect smooth transitions between ideas. They are not surprised by the unexpected topic switching and seem to share the understanding of it being appropriate.

\subsection{Metaparticipant understandings of the personal, interactional, and sociocultural contexts}

Spencer-Oatey and Kádár (2016) convincingly argued that both emic and etic approaches can contribute to (im)politeness research. Emic, culturespecific perspectives, such as beliefs and ideologies that influence moral order judgments, can help us comprehend the impact of contextual elements on interpersonal interaction and (im)politeness evaluations. Since moral perceptions are somehow intuitive, I draw metaparticipant understandings of the personal, interactional, and sociocultural contexts and moral expectations from the playback and gain emic conceptualizations from the participants' perceptions. Some of the metaparticipant understandings can corroborate aforementioned analyst understandings of the sociocultural context and participant understandings of the interactional context. Along with the participants' viewpoints, I also proffer insights as a metaparticipant in my analysis.

None of the ten interviewees (Jú, Wán, Zhēnlì, Yùhú, Fán, Cái, Kān, Xīn, Jùn, and Jiàn) notice anything abnormal in the playback. They state that they are unaware of the communicative act of unexpected topic switching. They explicitly employ the words 没看到 'didn't see,'没注意 'didn't notice,' or 没觉得 'didn't feel like' to describe their inattention to the existence of the act in the conversation clips. This indicates that the act is appropriate to them because interactants are inattentive to politic behavior (Watts 1989; 1992; 2003). But they would respond emotionally to impolite behavior (e.g., Culpeper et al. 2010; Langlotz \& Locher 2012) or comment on overly polite behavior (Kumon-Nakamura, Glucksberg \& Brown 2007). 
After I direct the interviewees' attention to the act, they deem it 正常 'normal' or 恰当 'appropriate.' In addition, some of them use other words, such as 自然 'natural,' 挺好 'fine,'没问题 'unproblematic,' or 没什么不好 'nothing bad' to make judgments of the act. This endorses Watts's (2003) argument that appropriate behavior is not as salient as polite or impolite behavior because it is what people normally do and expect.

The interviewees seem to concur that it is unnecessary to prepare addressees for topic switching in everyday communication. They tend to move onto the next topic directly or unexpectedly, instead of alerting addressees to the upcoming topic switching and providing signals, cues, or smooth transitions before changing the current topic. According to them, prefaced topic switching would sound more rigid and less natural in mundane conversations in Mandarin Chinese.

They justify their practice of unexpected topic switching by providing various personal, interactional, and sociocultural contextual factors, including sex, age, temperament, beliefs, habits, topics, risks, cues, social distance, status difference, interactional goals, settings, and regions. Their justifications mirror the immense effect of context on the moral order of topic switching. Context, to a great extent, constrains how topic switching is implemented and whether unexpected topic switching is (in)appropriate.

Apparently, the interviewees give less perceptual prominence to the linguistic structure of unexpected topic switching. Their perceptions allow them to deploy unexpected topic switching to achieve various purposes, including engaging side participants, seeking information, providing information, paying compliments, offering suggestions, sharing opinions, and sharing life experiences. Their perceptions are formed and reinforced by the practice of unexpected topic switching. Meanwhile, context affects what the interviewees expect others to say, what they select to interpret, and how they perceive unexpected topic switching.

The interviewees' perceptions are connected with the expectations that context helps to form. Their perceptions of (in)appropriate behavior are based on their normative anticipations as to what they expect people to do or say in the context concerned (Kádár \& Haugh 2013). Their "interpretations [...] relate to culturally based expectations as to what is acceptable or unacceptable behavior in the context in which it occurs" (Spencer-Oatey \& Kádár 2016, 74). This means that socioculturally shared norms can be the driving force of (im)politeness (Eelen 2001).

Some of the interviewees believe that the communicative act of unexpected topic switching is a part of the conversation norms among equals in the city of the data collection. The participants have experienced fre- 
quent exposure to the act in their community culture. They do not expect people or are not expected to avoid using it in informal talk about everyday topics. This understanding creates the basis of the community's expectations and perceptions of unexpected topic switching, which in turn leads to the performance of this act. The interviewees' evaluations of unexpected topic switching are based on the moral order in the community, which is common knowledge "of what social actions and meanings members think are appropriate/inappropriate, good/bad, polite/impolite and so on" (Kádár \& Haugh 2013, 67). The findings support Lee's (2011) discussion of cultural expectations, perceptions of (im)politeness, and social norms. Culturally-based beliefs can affect perceptions of (im)politeness and (in)appropriateness (Pan \& Kádár 2011).

\section{Conclusion}

In this paper, I have integrated the model of context, practice, and perception and the discursive-interactional approach to examine the rarelyexplored communicative act of unexpected topic switching in the collected mundane conversations in Mandarin Chinese. It is through both the analyst's and the participants' lens that I have gained diverse understandings of unexpected topic switching and found unexpected topic switching to be appropriate in the context of this study. The participants do not and are not expected to provide cues, discourse markers, or smooth transitions before changing topics in informal settings in mainland China. They seem to practice unexpected topic switching as a part of the moral order, which is constrained by sociocultural, interactional, and personal contexts. In different contexts, any points on the continuum of prefaced topic switching and unexpected topic switching could be sanctioned. "Which point on the scale is 'optimum' depends partly on pragmatic contextual variables and partly on culturally-based sociopragmatic preferences" (Spencer-Oatey \& Jiang 2003, 1635). This suggests that the moral order and moral perception of topic switching are context-bound.

The findings put into question universal pragmatics and the previous claim that topic switching should be prefaced in order to be appropriate. The study constitutes a part of the reinvestigation of stereotypes or presuppositions to reveal the use of the Chinese language from varying angles (Kádár 2007; 2008). Moreover, this study showcases the importance of encompassing multiple perspectives derived through triangulation of data sources to understand (im)politeness in sociocultural, interactional, and personal contexts. It answers Bunt \& Black's $(2000,2)$ call - "A clarifica- 
tion of what constitutes context [...] supplied by research in pragmatics, may provide much better analytic tools for the study of language in social contexts." On the other hand, the study calls for a revisit to topic switching in other Chinese contexts, because interactants tend to apply contextbased strategies of topic management to the construction of conversational coherence (Tannen 1981). Future research could examine topic switching patterns in other regions of China or other varieties of Chinese due to pragmatic variation across time and space (Barron \& Schneider 2009).

\section{Appendix A}

本项目旨在研究 中国人是怎样在日常生活中进行汉语会话交流。您被邀请参加本研究, 请填写以下信息, 因为您的信息对本研究很重要。即使未来在杂志上发表论文或会议上 宣读论文，您的信息都会保密。

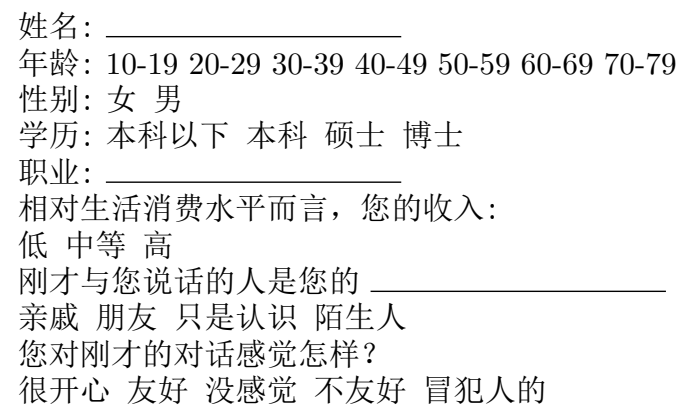

\section{Appendix B}

Transcription conventions (adapted from Schiffrin 1987)

Speaker turn start

A slight break between different parts of an utterance ,

A notable pause at the end of an utterance

Rise in intonation

Overlapping utterances

Contiguous utterances after an interruption

Omission

A short untimed pause within an utterance

Long untimed intervals within an utterance

An unfinished word

Laughter

Emphasis

Characteristics of the talk

Items in doubt

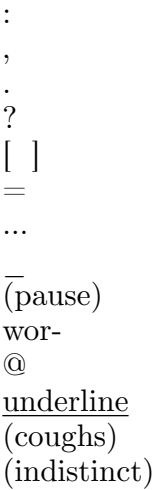




\section{Acknowledgments}

I would like to give a heartfelt thanks to Yùtíng Lán, Yángtiān Luó, and Jùn Wáng who helped me with data transcription, transcript check, and literature search; Prof. Jūn Wáng and her students who helped me with fieldwork, data transcription, and coding; and the participants who allowed me to record and study their conversations in informal contexts and those who I interviewed. I am also very grateful to the editors and the anonymous reviewers for their constructive feedback on earlier versions of this paper. Any remaining errors are mine.

\section{References}

Angouri, Jo and Miriam A. Locher. 2012. Theorising disagreement. Journal of Pragmatics 44. 1549-1553.

Austin, John Langshaw. 1962. How to do things with words. Cambridge, MA: Harvard University Press.

Barron, Anne and Klaus P. Schneider. 2009. Variational pragmatics: Studying the impact of social factors on language use in interaction. Intercultural Pragmatics 6. 425-552.

Bennett, Adrian. 1981. Interruption and the interpretation of conversation. Discourse Processes 4. 171-188.

Bian, Yanjie. 2001. Guanxi capital and social eating in Chinese cities: Theoretical models and empirical analyses. In N. Lin, K. Cook and R. Burt (eds.) Social capital: Theory and research. New Brunswick, NJ: Transaction Publishers. 275-295.

Bousfield, Derek and Miriam A. Locher. 2008. Impoliteness in language: Studies on its interplay with power in theory and practice. Berlin \& New York: Mouton de Gruyter.

Brown, Penelope and Stephen Levinson. 1987. Politeness: Some universals in language usage. Cambridge: Cambridge University Press.

Bunt, Harry and Bill Black. 2000. The ABC of computational pragmatics. In H. Bunt and W. Black (eds.) Abduction, belief and context in dialogue: Studies in computational pragmatics. Amsterdam \& Philadelphia: John Benjamins. 1-46.

Byon, Andrew Sangpil. 2006. The role of linguistic indirectness and honorifics in achieving linguistic politeness in Korean requests. Journal of Politeness Research 2. 247-276.

Chambliss, Catherine and Norah Feeny. 1992. Effects of sex of subject, sex of interrupter, and topic of conversation on the perceptions of interruptions. Perceptual and Motor Skills 75. 1235-1241.

Coon, Christine A. and Paula Schwanenflugel. 1996. Evaluation of interruption behavior by naïve encoders. Discourse Processes 22. 1-24.

Covelli, Lucille and Stephen Murray. 1980. Accomplishing topic change. Anthropological Linguistics 22. 382-389.

Culpeper, Jonathan. 2011. Impoliteness: Using language to cause offence. Cambridge: Cambridge University Press.

Culpeper, Jonathan, Derek Bousfield and Anne Wichmann. 2003. Impoliteness revisited: With special reference to dynamic and prosodic aspects. Journal of Pragmatics. 35-. $1545-1579$. 
Culpeper, Jonathan, Leyla Marti, Meilian Mei, Minna Nevala and Gila Schauer. 2010. Cross-cultural variation in the perception of impoliteness: A study of impoliteness events reported by students in England, China, Finland, Germany, and Turkey. Intercultural Pragmatics 7. 597-624.

Davidson, Lynne and Lucile Duberman. 1982. Friendship: Communication and interactional patterns in same-sex dyads. Sex Roles 8. 809822.

Dijk, Teun A. van 2006. Discourse, context and cognition. Discourse Studies 8. 159-177.

Eelen, Gino. 2001. A critique of politeness theories. Manchester: St. Jerome Publishing.

Freed, Alice. 1999. Communities of practice and pregnant women: Is there a connection? Language in Society 28. 257-271.

Gao, Ge. 1998. "Don't take my word for it": Understanding Chinese speaking practices. International Journal of Intercultural Relations 22. 163-186.

Garcés-Conejos Blitvich, Pilar. 2013. Introduction: Face, identity and im/politeness. Looking backward, moving forward: From Goffman to practice theory. Journal of Politeness Research 9. 1-33.

García, María Jesús Barros and Marina Terkourafi. 2014. First order politeness in rapprochement and distancing cultures: Understandings and uses of politeness by Spanish native speakers from Spain and Spanish nonnative speakers from the U.S. Pragmatics 24. 1-34.

Geluykens, By Ronald. 1993. Topic introduction in English conversation. Transactions of the Philological Society. 91. 181-214.

Giora, Rachel. 1998. Discourse coherence is an independent notion: A reply to Deirdre Wilson. Journal of Pragmatics 29. 75-86.

Goffman, Erving. 1974. Frame analysis: An essay on the organization of experience. New York: Harper and Row.

Goldberg, Julia. 1990. Interrupting the discourse on interruptions: An analysis in terms of relationally neutral, power- and rapport-oriented acts. Journal of Pragmatics 14. 883-903.

Goodwin, Charles and Alessandro Duranti. 1992. Rethinking context: An introduction. In A. Duranti and Ch. Goodwin (eds.) Rethinking context: Language as an interactive phenomenon. Cambridge: Cambridge University Press. 1-42.

Grice, H. Paul. 1975. Logic and conversation. In P. Cole and J. Morgan (eds.) Syntax and semantics Vol. 3. New York: Academic Press. 41-58.

Gumperz, John. 1982. Discourse strategies. Cambridge: Cambridge University Press.

Gumperz, John. 1992. Contextualization revisited. In Peter Auer and Aldo Di Luzio (eds.) The contextualization of language. Amsterdam \& Philadelphia: John Benjamins. $39-53$.

Haugh, Michael. 2007. The discursive challenge to politeness research: An interactional alternative. Journal of Politeness Research 3. 295-317.

Haugh, Michael. 2013. Im/politeness, social practice and the participation order. Journal of Pragmatics 58. 52-72.

Haugh, Michael and Francesca Bargiela-Chiappini. 2010. Face in interaction. Journal of Pragmatics 42. 2073-2077.

Hong, Wei. 1997. Gender differences in Chinese request patterns. Journal of Chinese Linguistics 25. 193-210.

\section{Acta Linguistica Academica 66, 2019}


Kádár, Dániel Z. 2007. Terms of (im)politeness: A study of the communicational properties of traditional Chinese (im)polite terms of address. Budapest: Eötvös Loránd University Press.

Kádár, Dániel Z. 2008. Power and (im)politeness in traditional Chinese criminal investigations. In H. Sun and D. Z. Kádár (eds.) It's the dragon's turn: Chinese institutional discourses. Berne: Peter Lang. 127-179.

Kádár, Dániel Z. and Michael Haugh. 2013. Understanding politeness. Cambridge: Cambridge University Press.

Kádár, Dániel Z. and Sara Mills. 2011. Introduction. In D. Z. Kádár and S. Mills (eds.) Politeness in East Asia. Cambridge: Cambridge University Press. 1-17.

Kuhn, Deanna. 1991. The skills of argument. Cambridge: Cambridge University Press.

Kumon-Nakamura, Sachi, Sam Glucksberg and Mary Brown. 2007. How about another piece of pie: The allusional pretense theory of discourse irony. In R. Gibbs and H. Colston (eds.) Irony in language and thought: A cognitive science reader. New York: Taylor and Francis. 57-96.

Lakoff, Robin. 1973. The logic of politeness, or minding your p's and q's. Chicago Linguistics Society 9. 292-305.

Langlotz, Andreas and Miriam A. Locher. 2012. Ways of communicating emotional stance in online disagreements. Journal of Pragmatics 44. 1591-1606.

Lee, Yu-Cheng. 2011. Cultural expectations and perceptions of politeness: The 'rude Chinese'? Asian Social Science 7. 11-23.

Leech, Geoffrey. 2007. Politeness: Is there an East-West divide? Journal of Politeness Research 3. 167-206.

Locher, Miriam A. 2004. Power and politeness in action: Disagreements in oral communication. Berlin \& New York: Mouton de Gruyter.

Locher, Miriam A. 2006. Polite behavior within relational work: The discursive approach to politeness. Multilingua 25. 249-267.

Locher, Miriam and Andreas Langlotz. 2008. Relational work: At the intersection of cognition, interaction and emotion. Bulletin Suisse de Linguistique Appliquée 88. 165-191.

Matsumoto, Yoshiko. 1988. Reexamination of the universality of face: Politeness phenomenon in Japanese. Journal of Pragmatics 12. 403-426.

Mills, Sara. 2009. Impoliteness in a cultural context. Journal of Pragmatics 41. 1047-1060.

Morris-Adams, Muna. 2014. From Spanish paintings to murder: Topic transitions in casual conversations between native and non-native speakers of English. Journal of Pragmatics 62. 151-165.

Murata, Kumiko. 1994. Intrusive or co-operative? A cross-cultural study of interruption. Journal of Pragmatics 21. 385-400.

Natale, Michael, Elliot Entin and Joseph Jaffe. 1979. Vocal interruptions in dyadic communication as a function of speech and social anxiety. Journal of Personality and Social Psychology 37. 865-878.

Pan, Yuling. 2000. Politeness in Chinese face-to-face interaction. Stamford, CT: Ablex Publishing Corporation.

Pan, Yuling and Dániel Z. Kádár. 2011. Politeness in historical and contemporary Chinese. New York: Continuum International Publishing Group. 
Schegloff, Emanuel A. 2001. Accounts of conduct in interaction: Interruption, overlap and turn-taking. In J. H. Turner (ed.) Handbook of sociological theory. New York: Kluwer Academic/Plenum Publishers. 287-321.

Schiffrin, Deborah. 1987. Discourse markers. Cambridge: Cambridge University Press.

Spencer-Oatey, Helen. 2008. Face, (im)politeness and rapport. In H. Spencer-Oatey (ed.) Culturally speaking: Culture, communication and politeness theory. London: Continuum. 11-47.

Spencer-Oatey, Helen. 2009. Face, identity and interactional goals. In F. Bargiela-Chiappini and M. Haugh (eds.) Face, communication and social interaction. London: Equinox. $137-154$

Spencer-Oatey, Helen and Dániel Z. Kádár. 2016. The bases of (im)politeness evaluations: Culture, the moral order and the East-West debate. East Asian Pragmatics 1. 73-106.

Spencer-Oatey, Helen and Wenying Jiang. 2003. Explaining cross-cultural pragmatic findings: Moving from politeness maxims to sociolinguistic interactional principles (SIPs). Journal of Pragmatics 35. 1633-1650.

Tannen, Deborah. 1981. Indirectness in discourse: Ethnicity as conversational style. Discourse Processes 3. 221-238.

Tannen, Deborah. 1984. Conversational style: Analyzing talk among friends. Norwood, NJ: Ablex.

Tannen, Deborah. 1990. Gender differences in topical coherence: Creating involvement in best friends' talk. Discourse Processes 13. 73-90.

Tryggvason, Marja-Terttu. 2004. Comparison of topic organization in Finnish, SwedishFinnish, and Swedish family discourse. Discourse Processes 37. 225-248.

Watts, Richard. 1989. Relevance and relational work: Linguistic politeness as political behavior. Multilingua 82. 131-166.

Watts, Richard. 1992. Linguistic politeness and politic verbal behavior: Reconsidering claiming for universality. In R. Watts, S. Ide and K. Ehlich (eds.) Politeness in language: Studies in its history, theory and practice. Berlin \& New York: Mouton de Gruyter. 43-70.

Watts, Richard. 2003. Politeness. Cambridge: Cambridge University Press.

Wu, Ruey-Jiuan Regina. 2014. Managing turn entry: The design of EI-prefaced turns in Mandarin conversation. Journal of Pragmatics 66. 139-161.

Zhu, Weihua. 2016. Extended concurrent speech and guānxi management in Mandarin. Text \& Talk 36. 637-660.

Zhu, Weihua. 2017. Perceptions of extended concurrent speech in Mandarin. Pragmatics 27. $144-170$. 